UDC 327-027.21/.22

Nataliya Khoma,

Doctor of Political Sciences, Professor,

Department of Political Science and International Relations,

Lviv Polytechnic National University,

ORCID ID: 0000-0002-2507-5741

nataliia.m.khoma@1pnu.ua

\title{
Yevhenija Voznyuk,
}

Candidate of Political Sciences (Ph.D.), associate Professor,

Department of International Relations and Regional Studies

Faculty of International Relations,

Lesya Ukrainka Volyn National University,

ORCID ID: 0000-0002-7828-7430

voznyuk.yevhenija@vnu.edu.ua

DOI 10.29038/2524-2679-2020-02-46

\section{EVOLUTION FROM THE CONCEPT «ZERO PROBLEMS WITH NEIGHBORS» \\ TO THE PRACTICE «ZERO NEIGHBORS WITHOUT PROBLEMS»: THE ROLE OF NEO-OTTOMANISM}

The peculiarities of Turkey's foreign policy in the Middle East in 2002-2020 are studied. Turkey's intentions to establish itself as an influential Eurasian state, which claims leadership in the Middle East, as well as in the Balkans, the Caucasus and Central Asia, were noted. The authors indicate the concept and foreign policy doctrine of "Zero Problems with Neighbors» as the ideological basis for Turkey's transition from a peripheral to a central role in international politics. It is emphasized that the doctrine of «Zero problems with neighbors» has become a revision of traditional Kemalist values in Turkey's foreign policy. The authors of the article evaluate the practical implementation of the doctrine as an unsuccessful attempt to become a regional leader in the Middle East. It was emphasized that at the beginning of the implementation of the concept of «Zero problems with neighbors» the only goal of the Turkish government was really to establish good neighborly relations, but after the beginning of the "Arab Spring» foreign policy strategy was revised. It was noted that in the last decade the Turkish government has reoriented to a more pragmatic foreign policy direction; it is determined by the main purpose of protecting its national interests; the result

(C) Khoma N., Voznyuk Ye., 2020 
was partial Turkey isolation. The article expresses author's vision that Turkey in its foreign policy has obviously moved from the concept of "Zero problems with neighbors» to the practice of «zero friends». It is proved that: 1) Turkey's relations with the Middle East (except Qatar) are quite tense; 2) although there is a partnership with many countries in the Middle East, it is often based on pragmatic mutual interest of countries, and cooperation often does not go beyond trade and economic relations.

Key words: Turkey, Turkey's Middle East policy, neo-Ottomanism, A. Davutoğlu, Justice and Development Party (Adalet ve Kalkınma Partisi, AKP), concept of «Zero Problems with Neighbors».

\section{INTRODUCTION}

The Middle East is a multi-conflict region. Most countries in the Middle East have strong geopolitical ambitions; they develop mainly neo-authoritarian models of governance, which is a threat to stability not only in the region but also overseas. In fact, it is the most conflict-prone region on the planet whose most accurate characteristic is «stable instability».

During its republican period between 1923 and 2002, Turkey paid little attention to the countries that used to be the provinces of the Ottoman Empire. Today, Turkey's foreign policy and national security strategies are based on the fact that this country must significantly influence the course of processes in the Middle East, as well as in the Balkans, the Caucasus and Central Asia. Turkey's latest foreign policy demonstrates Ankara's efforts to change the peripheral position into the central role in the international politics. The coming to power Justice and Development Party (AKP) in 2002 shifted the paradigm of Turkish politics. The priorities of Turkey's foreign policy became the intention to embody national geopolitical interests and to claim the regional leadership.

However, Turkey did not achieve the expected results in almost two decades of implementation of this course. Moreover, relationship with some participants of the Middle East policy have even deteriorated. Taking into consideration these processes, Turkey's policy towards the Middle East needs to be studied in order to identify possible vectors, determine potential threats, and assess the prospects of Turkey's leadership in the Middle East.

Researchers are proposing research approaches to Turkey's Middle East policy B. Akgün, P. Akpınar, M. Altunisik, B. Aras, A. Askerov, D. Bechev, E. Çuhadar, A. Davutoğlu, E. Ersoy, A. Görgülü, A. G.Gürzel, M. J. Koplow, Z. Öniş, M. Onsoy, M. Özkan, B. Pehlivantürk, M. Schaake, Ş. Yilmaz and others. 
Purpose of the Study is to examine Turkey's modern foreign policy in the Middle East. The tasks are defined: 1) to consider evolution of the concept of «Zero Problems with Neighbors» into a practice of «zero neighbors without problems»; 2) to reveal the role of neo-Ottoman ideology in this contradictory process.

Research methodology. The research methodology is based on the role theory (concepts of K. J. Holsti and Chih-yu Shih). «Role» refers to the policy pursued by a certain state (Turkey) in a particular region (Middle East). The role gives foreign policy purpose and content to the foreign policy, reflects the perception of Turkey as a member, as well as the leader, of international relations, in terms of place, position and behavior in a particular social reality of the Middle East. The category of role helps to understand Turkey's mission in the Middle East.

The role of Turkey is studied in vertical and horizontal dimensions. The vertical dimension involves reference to the majestic past of the state (in the case of Turkey, this is the period of the highest prosperity of the Ottoman Empire) and to the promising future (neo-Ottomanism conveys the dream of restoring the past greatness of Turkey). The horizontal dimension is expressed in the realization of the role through the interaction of Turkey with other participants of international relations, which also perform their roles. Within the scope of the analysis of Turkey's bilateral relations with the Middle East, the role of Turkey in the horizontal dimension is clarified.

Turkey is the proof that the choice of the role of the state in the past (vertical dimension) indicates the existence of problems that arise when searching for identity in the horizontal dimension. Turkey is trying to project the past (Ottoman) into the future (the potential leader of the Middle East region, and in the long run, the world superpower), to view current events and future plans through the past greatness of the Ottoman Empire and finds itself as its successor. Fear of remaining a secondary state has prompted Turkey to create a neo-Ottoman identity based on political Islam, but it is clear that this ideology is rejected by many Middle Eastern states.

If a state is satisfied with its current position at the regional or international levels in general, it tends to implement the national concept of the role in present, through an active interaction with other countries. This cannot be said of Turkey, as it not only idealizes the past, but its contemporary interaction with the Middle East is not an example of effective cooperation. Nowadays, Turkey has a public confrontation and tension with most states, and the relations that are still developing are more pragmatic, situational, rather than 
friendly and predictable. Turkey does not perform the desired role of the leader of the region due to a number of factors, however, the foreign policy of the country is aimed at it.

\section{FINDINGS OF THE STUDY}

In 2007-2010, Turkey actively implemented the concept of «Zero Problems with Neighbors», suggested by A. Davutoğlu. In 2009, it became the official foreign policy doctrine of the Republic of Turkey. Davutoğlu's concept was a revision of the traditional Kemalist values in foreign policy and aimed to consolidate Turkey's status as a regional leader and turn it into a world power.

Davutoğlu's approach was based on the understanding that the absence of issues with neighbors will allow Turkey to focus on solving domestic problems, to develop the economy. If this task is embodied, the country will play an important role in Europe, the Middle East, the Caucasus, and Central Asia due to its geopolitical position. As a result, there will not be any significant matters in these areas that could be resolved without the participation of Turkey. At first, Ankara's only goal in implementing the concept of "Zero Problems with Neighbors" was to enhance relations with neighboring countries. However, later there was a transformation to aggressive mechanisms that would change the status of the country by managing political processes in neighboring states.

Referring to the approaches of the previous Minister of Foreign Affairs of Turkey İsmail Cem, Davutoğlu directed the AKP to establish good neighborship with Greece and Cyprus [14]. Moreover, in 2009-2010, attempts were made to stabilize relations with Armenia [10]. The tension between countries has persisted since the First World War. Since Ankara had many difficult issues with its neighbors, the actualization of Davutoğlu's concept seemed an insurmountable task, however, at that time Turkey acquired the necessary resources to implement it due to the economic boom.

Initiatives for rapprochement with Armenia and reconciliation with $\mathrm{Cy}-$ prus have only intensified public discourse, but Turkey has yielded the expected result. Some other Turkish actions, such as refusing to impose sanctions on Iran , refusing to deploy NATO X-Band radars, supporting the Kurdistan regional government as a fully independent entity from Baghdad in Iraq, etc., jeopardized the West and Turkey's regional neighbors [12]. After the beginning of the civil war in Syria, Turkey was embroiled in a confrontation with three participants in the conflict, whom it determines as terrorists. They are the Kurdistan Workers' Party, the Islamic State group, and the opposition movement of Gülen (the Gülenists) [21]. 
Davutoğlu's concept of «zero problems with neighbors » quickly acquired the ambitious goal to resolve all disputes that concerned Turkey directly or indirectly. Attempting to spread its power, Turkey has declared its intention to expand its interests to Africa [17], the Balkans [22], even Latin America [16] and East Asia [18]. Turkey has taken on the role of the peacemaker between Israel and Syria [4], Serbia and Bosnia and Herzegovina [6], the Palestinian groups Hamas and Fatah [3], Iran and the West [11], the hostile parties in Somalia [1], etc.

Since some states with which Ankara sought to have «zero problems» had authoritarian regimes, this contradicted the role that the AKP had defined for itself, that is a beacon of democratization. This problem became apparent in the summer of 2009, when Iran suppressed the opposing Iranian Green Movement. Ankara did not react critically to these actions, unlike many world leaders. As a result, Turkish leaders began to realize that advancing a policy of «zero problems» could lead to accusations that they were pursuing a course of «zero problems with dictators » [2]. Following this conclusion, Turkish leaders condemned the Assad regime in Syria (relations have deteriorated rapidly since 2011) and supported the Syrian opposition. This position emerged from the fact that the AKP advocated itself as a democratic force that was able to remove the military from the governance (though, it was the military who saw themselves as guardians of the ideals of Kemal (Atatürk) and secular Turkish nationalism).

Turkey's foreign policy of «zero problems with neighbors» had some positive outcomes for some time, but the Arab Spring and the Syrian civil war have made significant adjustments to its implementing feasibility. While Turkey's ambitions grew, its real achievements in foreign policy diminished [24]. Most of the Turkey's international efforts have not been successful [8].

We assume that the events of the Arab Spring forced Turkey to change the focus from «soft» to more «hard» mechanisms of its foreign policy. The practical implementation of such concepts as «strategic depth», «rhythmic diplomacy», «multidimensional foreign policy», which were promoted by Davutoğlu, proved to be difficult in the context of the dynamic changes in the political landscape of the Middle East after the «Arab Spring». Since 2011, Turkey's foreign policy doctrine has been revised under the influence of political transition and rising instability in the Middle East. From Davutoğlu's point of view, the revolutionary events in the Arab countries of the Middle East were natural and inevitable, and therefore it is necessary to understand thoroughly the reasons for this transformation and develop an appropriate strategy to respond to change. Thus, the idealistic vision of «Zero Problems 
with Neighbors» in practice began to coexist with Turkey's pragmatic reactions to the current challenges and its transformation into an interventionist. In particular, this idea, is developed by the Dutch researcher and politician M. Schaake. She believes that «Arab Spring» created a number of problems for Turkey's implementation of the «Zero problems with neighbors» course [20], and the Arab street's calls for human rights prompt this topic in Turkey itself.

So, the practical implementation of the concept of «Zero problems with neighbors» became less effective after 2011. Then, tensions in relations with Israel increased, new (in addition to the territorial conflict) disputes with Cyprus over geological exploration in the Mediterranean arose, cross-allegations between Erdoğan and Iraqi Prime Minister Haider al-Abadi intensified, and ties with Iran deteriorated as a result of Turkey's participation in NATO's «nuclear shield», etc. Although, Turkish officials continued to claim that the vision of no problems in relations with neighbors still works, they did not object to revise this concept in the context of Turkey's numerous problems in the international dimension. It has already been said that at this stage «Zero problems» exist in relations with peoples, not with governments [7]. We should note that from the content posted on the official website of the Ministry Foreign Affairs of the Republic of Turkey, it is obvious that the state continues to officially declare the implementation of the concept of «Zero problems with neighbors» despite the evident discrepancy between the declarations and reality [19].

Researchers correctly call the policy of no problems with neighboring countries «idealistic» [5], because this kind of approach is vulnerable to dynamic political and economic events in the region and the world. It is clear that in recent years, the Turkish government has actually abandoned it and refocused on a foreign policy course based on the realistic approaches that protect its national interests. Such an ambitious policy has led to the opposite results and the current stage of Turkey's foreign policy is called «precious loneliness» [9].

The countries in which Turkey pursued a zero-problem course realized that this way Turkey was reviving its Ottoman identity. However, for some time they pragmatically tried to derive their national benefit from the implementation of the flexible concept of «Zero problems with neighbors». This situation could not be sustained for a long time, various conflicts intensified. Consequently, the implementation of the concept of «Zero problems with neighbors» has turned from a large-scale plan into an unfeasible political utopia. Davutoğlu was sarcastically called Mr. «Zero Problems», and in the 
political discourse Turkey's foreign policy is increasingly described as the concept of «Zero problems with neighbors» converting to the practice of «zero friends».

Historical memory and nationalist policies seem to have made not only the institution of the state but also the citizens of Turkey increasingly isolated. Results of recent opinion polls demonstrate this tendency [23]. At the end of 2019, Kadir Has University conducted a public poll among the Turkish population regarding a wide range of domestic and foreign policy issues. Turkish respondents considered Azerbaijan (56,5\%) and the unrecognized Republic of Northern Cyprus $(43,1 \%)$ as the main foreign policy friends and allies. We should mention that for all countries covered by the survey, there was a decrease in the percentage of respondents who classified them as «friend», «ally». Slight downward fluctuations were observed only in the case of Qatar and India; for other countries, the gap between the indicators of monitoring surveys in 2018 and 2019 was significant. Such results can be explained due to the start of Turkey's military operations in northern Syria and a massive negative assessment of these actions by almost all the states. After the beginning of the Turkish intervention in Syria (Operation Peace Spring) and the announcement by world leaders of the possibility of imposing economic sanctions on Turkey, the Turkish public felt that «everyone is against them». At the same time, this opinion is found in all the socio-demographic groups in Turkish society. We assume that after the negative reaction of the world to the deployment of Turkish troops to Libya (January 2020) and to the Turkey's new military operation in Syria («Spring Shield») at the beginning of March 1,2020 , the percentage of those who would include certain states among the allies would be even lower.

Turkey's relations with its neighbors and with the Middle East in general (with the exception of Qatar) are quite strained. Although, a mutually beneficial partnership has been established with many countries in the region, it is often based on the recent pragmatic interest of countries in each other, therefore, the real cooperation is nothing more than trade and economic relations.

Over the past decade, Turkey has deviated from its image of Islamic democracy toward neo-authoritarianism. In fact, it is isolated from its neighbors. However, this does not completely explain the growing antagonism in the relations with most of the Middle East countries, as majority of them are also repressive authoritarian states. It is possible that the reason is the activities of Erdoğan to promote the political Islam, both domestically and internationally. This brings Turkey closer to Qatar, but causes tensions with many other Arab states, most notably Saudi Arabia, the UAE, Egypt, Bahrain, and others. 
The «zero problems» approach has become a tight knot of problems involving many participants of the international politics. The Turkish concept of «Zero problems with neighbors» has become a practice of «zero neighbors without problems» [13]. From the very beginning, the implementation of the Turkish foreign policy concept did not correspond to its content: «zero» was defined as something too relative, while «neighbors» were depicted selectively. It is possible that this name was used to conceal intentions to establish regional hegemony. Consequently, nowadays Turkey has almost zero chances of «zero problems with its neighbors».

\section{CONCLUSIONS AND PROSPECTS FOR FURTHER RESEARCH}

Turkey's current foreign policy is a reflection of fears to remain a minor, buffer state against the background of the past greatness of the Ottoman Empire. Turkey refered to the traditional foundations of Turkish foreign policy (Ottomanism, Pan-Turkism), which are radically different from pro-Western Kemalism. The neo-Ottoman shift of Turkey is explained by the peculiarities of the geopolitics of the post-bipolar period, presence of conflicting identities, the intention to take responsibility for certain negative (from Turkey's point of view) processes in the countries of «Ottoman heritage» (European, Asian and African territories), etc. Turkey has set itself the task of reaching a new (supraregional) level through the revival of political Islam, Ottoman traditions and ideology. At the same time, officially Turkey is distancing itself from neo-Ottomanism in order to avoid accusations of commitment to expansionism. However, expansionism is evident both at the doctrinal level (for example, the Blue Homeland doctrine) and at the practical level (for instance, activity in the economic maritime zones of Greece and Cyprus). Despite the fact that Turkey separates from the characterization of its foreign policy as neo-Ottomanism, specifically Islamist neo-Ottomanism is the ideology of the country's modern foreign policy.

Davutoğlu's «Zero Problems with Neighbors» doctrine remains the conceptual basis for Turkey's aim to overcome inferiority in world politics. However, after the events of the Arab Spring, especially after the attempted coup d'etat in Turkey in 2016, this doctrine has transformed from an intensification of peaceful cooperation with neighboring countries to the usage of aggressive mechanisms. The transition to a new stage in Turkey's foreign policy, The Post-Davutoglu Era, is obvious. In fact, at this stage, the emphasis has shifted from «soft» to more «hard» foreign policy tools, formed according to the ideology of Islamist neo-Ottomanism. 
The idealistic vision of «zero problems with neighbors» course has practically begun to coexist with Turkey's pragmatic reactions to current challenges and its transformation into an interventionist with «zero friends» (with the exception of Qatar which is interested in partnering with Turkey). The style of foreign policy has become much more aggressive, resulting in accusations of Turkish colonial illusions. So far, Turkey has not only failed to increase its influence and prestige in the Middle East, but due to the support for the Muslim Brotherhood, the 2019-2020 military actions in northern Syria, the deployment of troops in Libya, etc. it united in opposition most countries in the world, even those that compete with each other at the international level.

\section{REFERENCES}

1. Akpınar, P. (2013). Turkey's Peacebuilding in Somalia: The Limits of Humanitarian Diplomacy. Turkish Studies, 14 (4), 735-757 (in English).

2. Akyol, M. (29 Jun. 2016), The Problem With Turkey's 'Zero Problems' Plan. The New York Times (in English).

3. Altunisik, M., Çuhadar, E. (2010). Turkey's Search for a Third Party Role in Arab-Israeli Conflicts: A Neutral Facilitator or a Principal Power Mediator? Mediterranean Politics, 15 (30), 371-392 (in English).

4. Aras, B. (2009). Turkey's Rise in the Greater Middle East: Peace-Building in the Periphery. Journal of Balkan and Near Eastern Studies, 11 (1), $29-41$ (in English).

5. Askerov, A. (2017). Turkey's «Zero problems with neighbors» policy: Was it realistic? Contemporary Review of the Middle East, 4 (2), 149-167 (in English).

6. Bechev, D. (2012). Turkey in the Balkans: Taking a Broader View. Insight Turkey, 14 (1), 131-146 (in English).

7. Davutoglu, A. (2012). Principles of Turkish Foreign Policy and Regional Political Structuring. SAM Vision Papers, 3 (in English).

8. Eralp, D. U. (Ed.) (2016). Turkey as a Mediator: Stories of Success and Failure. Lanham, Md.: Lexington Books (in English).

9. Gardner, D. (15 Nov. 2015). Turkey's Foreign Policy of «Precious Loneliness». Financial Times (in English).

10. Görgülü, A. (2009). Towards a Turkish-Armenian Rapprochement? Insight Turkey, 11 (2), 19-29 (in English).

11. Gürzel, A. G., Ersoy, E. (2012). Turkey and Iran's Nuclear Program. Middle East Policy, 19 (1), 37-50 (in English).

12. Koplow, M. J. (20 Feb. 2014). False Friends: Why the United States Is Getting Tough with Turkey. Foreign Affairs (in English).

13. Makarian, P. C. (19 Jan. 2016). Turquie: état fort, maillon faible. L'Express (in English).

14. Öniş, Z. (2011). Multiple Faces of the 'New' Turkish Foreign Policy: Underlying Dynamics and a Critique. Insight Turkey, 13 (1), 47-65 (in English).

15. Öniş, Z., Yilmaz, Ş. (2008). Greek-Turkish Rapprochement: Rhetoric or Reality? Political Science Quarterly, 123 (1), 123-149 (in English). 
16. Onsoy, M. (2017). Latin America-Turkey Relations: Reaching Out to Distant Shores of the Western Hemisphere. In: P. G. Ercan (Ed.), Turkish Foreign Policy: International Relations, Legality and Global Reach. London: Palgrave Macmillan (in English).

17. Özkan, M., Akgün, B. (2010). Turkey's Opening to Africa. The Journal of Modern African Studies, 48 (4), 525-546 (in English).

18. Pehlivantürk, B. (2017). East Asia in Turkish Foreign Policy: Turkey as a 'Global Power'? In: P. G. Ercan (Ed.), Turkish Foreign Policy: International Relations, Legality and Global Reach. London: Palgrave Macmillan (in English).

19. Policy of Zero Problems with our Neighbors. URL: http://www.mfa. gov.tr/ policy-of-zero-problems-with-our-neighbors.en.mfa (in English)

20. Schaake, M. (2011). Zero Problems? Time for a New Policy Narrative. Turkish Policy Quarterly, 10 (1), 47-52 (in English).

21. Taş, H. (2018). A History of Turkey's AKP-Gülen Conflict. Mediterranean Politics, 23 (3), 395-402 (in English).

22. Türbedar, E. (2011). Turkey's New Activism in the Western Balkans: Ambitions and Obstacles. Insight Turkey, 13 (3), 139-159 (in English).

23. Türkiye Eğilimleri-2019 (2020). URL: https://www.khas.edu.tr/sites/ khas.edu. tr/files/ inlinefiles/TE2019_TUR_WEB_15.01.20.pdf (in English).

24. Zalewski, P. (22 Aug. 2013). How Turkey Went from «Zero Problems» to Zero Friends. Foreign Policy (in English).

\section{ЕВОЛЮЦІЯ ВІД КОНЦЕПЦІї «НУЛЬ ПРОБЛЕМ ІЗ СУСІДАМИ» ДО ПРАКТИКИ «НУЛЬ СУСІДІВ БЕЗ ПРОБЛЕМ»: РОЛЬ НЕООСМАНІЗМУ}

Досліджено особливості зовнішньої політики Туреччини на Близькому Сході у 2002-2020 pр. Відзначено наміри Туреччини утвердитися на позиціях впливової євразійської держави, яка претендує на лідерство в регіоні Близького Сходу, а також на Балканах, Кавказі, у Центральній Азії. Указано на концепцію та зовнішньополітичну доктрину «Нуль проблем із сусідами» як ідеологічну основу переходу Туреччини з позицій периферійного на позиції центрального а́ктора міжнародної політики. Наголошено, що доктрина «Нуль проблем із сусідами» за змістом стала переглядом традиційних кемалістських цінностей у зовнішній політиці Туреччини. Зроблено оцінку практичної реалізації Туреччиною згаданої доктрини як наразі неуспішної спроби стати регіональним лідером Близького Сходу. Підкреслено, що на початку реалізації концепції «Нуль проблем із сусідами» єдиною метою турецької влади справді було налагодження добросусідських відносин, але після початку «Арабської весни» зовнішньополітичну стратегію переглянуто. Зауважено: в останнє десятиліття турецький уряд переорієнтувався на більш прагматичний 
курс зовнішньої політики; цей курс визначається метою захисту своїх національних інтересів; наслідком стала деяка ізольованість Туреччини. Висловлено авторське розуміння того, що Туреччина у своїй зовнішній політиці, вочевидь, перейшла від концепції «Нуль проблем із сусідами» до практики «нуль друзів». Аргументовано: 1) відносини Туреччини 3 державами Близького Сходу (за винятком Катару) є доволі напружені; 2) хоч і з багатьма державами Близького Сходу наявне партнерство, але в його основу найчастіше покладено прагматичну взаємозацікавленість країн, а співпраця часто не виходить за рамки торговельно-економічних відносин.

Ключові слова: Туреччина, близькосхідна політика Туреччини, неоосманізм, А. Давутоглу, Партія справедливості та розвитку, концепція «Нуль проблем із сусідами».

Матеріал надійшов до редакиї 16.11.2020 p. 